\title{
Catholics and the Campaign for Women's Suffrage in England
}

\author{
ELAINe Clark
}

Narratives about women and religion in Victorian and Edwardian society seldom addressed the world of the Catholic laity, leaving the impression that Catholics were unimportant in English history. ${ }^{1}$ Pushed into anonymity, they were easily misunderstood because of their religious sensibilities and loyalty to a church governed not from London but Rome. This was a church long subject to various forms of disability in England and with a membership of roughly 5 percent of the population around $1900 .^{2}$ By then, objections to the Catholic Church as a foreign institution had lessened, but critics still labeled Catholics "a people apart," viewing them as too disinterested in their neighbors" welfare to play a vital part in public life. ${ }^{3}$ So commonplace was this particular point of view that it obscured Catholic participation in social causes such as the hard fought campaign for women's suffrage. As often as journalists, suffragists, and members of Parliament debated enfranchisement in the years before and after the First World War, very little is known today about the role Catholics played in the struggle for women's rights.

There are studies of politically active Quakers, Anglicans, and Unitarians, but few comparable studies of the Catholics they knew as

1. See Gail Malmgreen, ed., Religion in the Lives of English Women, 1760-1930 (London: Croom Helm, 1986), 2: "the historiography of Roman Catholic laywomen, for example, is all but non-existent." A notable exception is Paula M. Kane, "The Willing Captive of Home?': the English Catholic Women's League, 1906-1920," Church History 60:3 (1991): 331-55.

2. Demographic information about Catholics is, at best, approximate. See George Andrew Beck, "Today and Tomorrow," in The English Catholics, 1850-1950, ed. Beck (London: Burns and Oates, 1950), 587. Edward Norman, Roman Catholicism in England from the Elizabethan Settlement to the Second Vatican Council (Oxford: Oxford University Press, 1985), 108. For earlier references, see Tablet, 15 February 1898, 307; 24 December 1898, 1022; 5 August 1899, 203; 22 March 1902, 45.

3. Catholic writers responded to this criticism. See James Britten, "The Catholic Conference, 1900," Month 96 (July 1900): 62-70. Virginia M. Crawford, Ideals of Charity (London: Sands, 1908), 1-13. Also, see remarks of Frances Zanetti, "Annual Conference of Catholic Truth Society," Tablet, 30 September 1905, 541.

Elaine Clark is professor of History at the University of Michigan-Dearborn. 
friends, confidantes, and workers in the suffragist cause. ${ }^{4}$ Althoughwomen as notable as Charlotte Despard and Alice Meynell were the subjects of biography and memoir, their influence on Catholic feminism remains largely unexplored. ${ }^{5}$ Somewhat better known is the Catholic Women's Suffrage Society, which began its organizational work in 1911. ${ }^{6}$ Drawing supporters from London and various provincial towns, the founding members understood that the cause they

4. Brian Heeny, The Women's Movement in the Church of England, 1850-1930 (Oxford: Clarendon, 1988). Kathryn Gleadle, The Early Feminists: Radical Unitarians and the Emergence of the Women's Rights Movement, 1831-1851 (New York: St. Martin's, 1995). Jane Rendall, "Friendship and Politics: Barbara Leigh Smith Bodichon (1827-91) and Bessie Rayner Parkes (1829-1925)," in Sexuality and Subordination: Interdisciplinary Studies of Gender in the Nineteenth Century, eds. Susan Mendus and Jane Rendall (London: Routledge, 1989), 136-70. Sheila R. Herstein, A Mid-Victorian Feminist, Barbara Leigh Smith Bodichon (New Haven, Conn.: Yale University Press, 1985). Sandra Stanley Holton, Suffrage Days: Stories from the Women's Suffrage Movement (London: Routledge, 1996), 161-81. For reference to Catholic involvement in suffrage campaigns in places outside of England, see Cliona Murphy, "The Religious Context of the Women's Suffrage Campaign in Ireland," Women's History Review 6:4 (1997): 549-65; and The Women's Suffrage Movement and Irish Society in the Early Twentieth Century (New York: Modern Language Association, 1989), 138-63. Steven C. Hause and Anne R. Kenney, "The Development of the Catholic Women's Suffrage Movement in France, 1896-1922," Catholic Historical Review 67:1 (1981): 11-30; and Women's Suffrage and Social Politic in the French Third Republic (Princeton, N.J.: Princeton University Press, 1984), 7, 20-30, 61-67, 81-87, 217-21, 260. James F. McMillan, "Women in Social Catholicism in Late Nineteenth- and Early Twentieth-Century France," in Women in the Church, eds. W. J. Sheil and Diana Wood (Oxford: Blackwell, 1990), 467-80; and "Wollstonecraft's daughters, Marianne's daughters and the daughters of Joan of Arc: Marie Maugeret and Christian Feminism in the French Belle Epoque," in Wollstonecraft's Daughters: Womanhood in England and France, 1780-1920, ed. Clarissa Campbell Orr (Manchester, U.K.: Manchester University Press, 1996), 186-98. James J. Kenneally, "Catholicism and Woman Suffrage in Massachusetts," Catholic Historical Review 53:1 (1967): 43-57; and The History of American Catholic Women (New York: Hearst Books, 1990), 131-44.

5. Andro Linklater, An Unhusbanded Life: Charlotte Despard, Suffragette, Socialist and Sinn Feiner (London: Hutchinson, 1980). Margaret Mulvihill, Charlotte Despard: A Biography (London: Pandora, 1989). Alice Kimball Tuell, Mrs. Meynell and Her Literary Generation (New York: E. P. Dutton, 1925). Viola Meynell, Alice Meynell: A Memoir (New York: Scribner's Sons, 1929). Sir Frances Meynell, "Memoirs of My Mother," Poetry Review 47 (July-September 1956): 142-46, (October-December 1956), 214-18. June Badeni, The Slender Tree: A Life of Alice Meynell (Pastow, Cornwall, U.K.: Tabb House, 1981). Writing in the Catholic Citizen, 15 December 1929, 96-97, Leonora de Alberti remarked that Mrs. Meynell's "work for Catholic feminism" was yet to be fully recorded.

6. Leonora de Alberti, "A History of the Catholic Women's Suffrage Society," Catholic Citizen, 15 October 1928, 77-81; 15 November 1928, 92-96; 15 December 1928, 104-8. Georgiana Putnam McEntee, The Social Catholic Movement in Great Britain (New York: Macmillan, 1927), 238-40. Phyllis C. Challoner and Vera Laughton Mathews, Towards Citizenship: A Handbook of Women's Emancipation (London: King, 1928), 68-87. Nancy Steward Parnell, "A Venture in Faith. A History of St. Joan's Social and Political Alliance, Formerly the Catholic Women's Suffrage Society, 1911-1961," St. Joan's Alliance pamphlet (London, 1961, reprinted 1980). Francis M. Mason, "The Newer Eve: The Catholic Women's Suffrage Society in England, 1911-1923," Catholic Historical Review 72:4 (1986): 620-38. 
espoused had a Catholic history extending beyond their own concerns to include the clerical and lay opinion of an earlier age.

By the 1880s this opinion had brought into focus the politically divisive attitudes that complicated Catholic debate about women's suffrage, a debate that was joined after the turn of the century by a growing number of Catholic suffragists. Theirs was a detailed and purposeful agenda. Reduced to its simplest terms, it presented women's suffrage as a matter of "elementary justice" and insisted that "the difficult and arduous work of the women reformers is essentially and fundamentally a moral work" based on the "moral principle of true sex equality." Although the vote was critically important, it was a means and not an end for these reformers. They believed there was an equally pressing need for the active participation of Catholic women in all that concerned women's work and women's emancipation. Collective efforts to make the suffrage campaign a significant "mission" for women clearly mattered to Catholic activists as did the struggle to make the public culture more inclusive.

The record of this struggle is long and fairly detailed. In its detail it points to a past more reflective of the agency of Catholics than historians have supposed and calls attention to the process by which reforming women challenged the notion that Catholicism and feminism were incompatible. That it was unnecessary to choose between the two was the position of a number of strong-minded women. Among them were Elisabeth Christitch, Alice Meynell, Virginia Crawford, Leonora de Alberti, Christopher St. John, and Alice Abadam. ${ }^{8}$ All belonged to a generation of reformers who were born

7. See comments of Alice Abadam in Tablet, 17 August 1912, 259; Alice Meynell in Catholic Suffragist, 15 January 1915, 1-2; Virginia Crawford in Catholic Citizen, 15 June 1922, 64.

8. ELISABETH O'BRIEN CHRISTITCH (ca. 1862-1933) was born and raised in Ireland; became a governess in Poland; married Lubomir Christitch, a Serbian military officer with whom she lived in Belgrade and in Russia when he held a diplomatic position at the Imperial Court. An accomplished journalist, she wrote on Serbian affairs for the Times (London) and the Chicago Tribune. She spent a number of years in London and was an outspoken supporter of Irish Home Rule. VIRGINIA SMITH CRAWFORD (1862-1948) was a social activist, prolific writer, supporter of the Labour Party, Poor Law Guardian, and Borough Councillor of St. Marylebone. Unhappily married to Donald Crawford (1837-1919), she was party to a sensational divorce case in 1886 that generated intense, seemingly endless, publicity. See Roy Jenkins, Sir Charles Dilke: $A$ Victorian Tragedy (London: Collins, 1958). CHRISTOPHER ST. JOHN (Christabel Marshall) (ca. 1875-1960) was an Oxford educated journalist, dramatist, and biographer. She edited Ellen Terry and Bernard Shaw: A Correspondence (London: Constable, 1931) and from 1899-1947 lived with Terry's daughter, Edith Craig. See Nina Auerbach, Ellen Terry: Player in Her Time (New York: W. W. Norton, 1987); and Katharine Cockin, Edith Craig (1867-1947): Dramatic Lives (London: Cassell, 1998). ALICE ABADAM (ca. 1856-1940) was born in Wales and by 1910 was widely regarded as a gifted orator; she traveled throughout Britain as a speaker to various suffrage 
and came of age during the Victorian era. All were accomplished workers in their chosen fields. Each created for herself an identity as a feminist and a Catholic. At issue, then, is not simply their support for the parliamentary franchise, but whether this support can be understood in broader terms. If Catholics were "a people apart," if they occupied a separate world-at least in an institutional sensewere Catholic suffragists able to effect change in the larger society; or was it the case that their efforts had relevance for Catholic opinion alone?

\section{I. $1850-1896$}

For the better part of the nineteenth century, public opinion in the small world of England's Catholics was the opinion of laymen and priests. Their voices dominated the Catholic press and influenced the discussion of political issues in newspapers, pamphlets, and monthly journals. As this literature accumulated, it reminded readers that Catholic spokesmen were, when it came to women's rights, men of their time. If they took notice of women's status, their response was more often a terse commentary on the politics of the day than a brief for giving women a place in public affairs. This certainly was true in the 1850s when the Roman Catholic hierarchy was reestablished in England, and Nicholas Wiseman became Cardinal Archbishop of Westminster. In 1852, Wiseman wrote about "lady theologians" in the Dublin Review, a Catholic quarterly that endorsed, as did he, a traditional view of "woman's mission." This mission, he explained, "is a mission of quiet, silent work; . . its sphere is the small, unpretending one of women's duty -in the school, in the cottage, in the garret, in the hospital-but mainly at home." 9 Should women step out of their "appropriate sphere," Wiseman added, they would forfeit "rights" and lose "the respect of those who like to see every lady in her own place." ${ }^{10}$

Not only Cardinal Wiseman but many Protestant clerics and statesmen shared the opinion that a woman's mission, while important, lay

societies. In 1926, she was president of the Feminist League. See Tablet, 25 December 1911, 203; 23 March 1912, 470; Alice Meynell, "A Tribute to Miss Abadam," 27 July 1912, 125-26. LEONORA DE ALBERTI (ca. 1863-1934) was an archivist and paleographer at the British Museum and the Public Record Office. An ardent internationalist, she was an occasional editor of Jus Suffragii, Honorary Secretary of the Council for the Representation of Women on the League of Nations, committee member of the Open Door Council and British Commonwealth League. She founded the Catholic Suffragist in 1915 and served as its editor until her death. ALICE THOMPSON MEYNELL (1847-1922). Distinguished poet and essayist; see note 5.

9. (Nicholas Wiseman), "Lady Theologians," Dublin Review 32 (March 1852): 258.

10. Ibid. 
in "another direction than the House of Commons." ${ }^{11}$ When prosuffrage voices sounded in the 1860s, harsh words colored the commentary and editorials of the Catholic press. The Dublin Review, the Tablet, and the Month deplored the "clamour" of suffragists and denounced "female emancipation" as the "ridiculous" and fanciful theory of "shallow philosophers." ${ }^{12}$ To talk of women's rights, claimed the Dublin Review, was "nonsense"; the Tablet, a Catholic weekly, concurred. ${ }^{13}$ So did the Month, a Jesuit periodical that used its columns in 1869 to criticize John Stuart Mill, saying that his "rather feminine attack upon man as a tyrannical usurper of power over women is so little likely to have any practical influence that it is not necessary to be here at any pains to refute him.." ${ }^{14}$ The Archbishop of Westminster, Henry Edward Manning, was just as dismissive of the "woman question," particularly in a lecture he delivered in London during Lent 1871. To a large audience assembled at Moorfields, Manning said among other things: "I trust that the womanhood of England ... will resist by a stern moral refusal, the immodesty which would thrust women from their private life of dignity and supremacy into the public conflicts of men." ${ }^{15}$ Even though he was an advocate of social reform, Manning chose not to support the suffragist cause. Equality between the sexes, he believed, would not "elevate" but "degrade" a woman by involving her in the dirt and strife of political life.

During the 1870 s no Catholic apologist, not even Manning, made a more concerted effort to influence popular views of women's suffrage than the staff of the London-based Tablet. "We have a dread of women in public life," its editors wrote in 1871, "and we very much fear that women will change their nature and become more like those of the first French Revolution than is good for either them or us." ${ }^{16}$ The political effort to make woman the equal of man seemed to Catholic commentators a misguided attempt "to repeal the prescription of the Old and the New Testament, and to reform Christianity upon a nineteenth-century model."17 When the Spectator offered a different view, the Tablet said: "we wonder whether the Spectator has burned its

11. "The Female Vote," Tablet, 14 November $1868,41$.

12. Ibid. Also see "The Employment of Women," Dublin Review 52 (November 1862): 6, 39; and "The Subjection of Women," Month 11 (August 1869): 205-6.

13. "The Employment of Women," 7; Tablet, 12 June 1869, 50.

14. "The Subjection of Women," 205.

15. Manning's lecture is discussed in the Tablet, 9 September 1871, 334-35. For text, see William Samuel Lilly, ed. Characteristics: Political, Philosophical, and Religious from the Writings of Cardinal Manning (London: Burns and Oates, 1885), 61.

16. “Women's Rights," Tablet, 13 May 1871, 579.

17. Ibid., 575 . 
Bible." ${ }^{18}$ At issue for both journals was "the notion of women's rights," a notion which the Tablet believed so clearly contradicted the order God had established in the world that "the proposal to turn women into Parliamentary constituents" was "ludicrous," "hideous," and "fundamentally immoral."19 In May 1872, when Jacob Bright spoke in Westminster on behalf of his Women's Disabilities Bill, the Tablet noted his "good-natured concession" in confining enfranchisement to unmarried women, then belittled his Bill as "an attempt to amend the laws of creation." 20 To ignore these laws, said a writer for the Month, was to encourage political propagandists "to unwoman woman and make her another man." ${ }^{21}$

The opposition of the Catholic press to women's suffrage continued into the 1880s, with opponents of the parliamentary franchise claiming that "Catholic heroines" of an earlier day-Madeleine Sophie Barat, Elizabeth Seton, Madame Swetchine-had led admirably productive lives even though the work they accomplished never involved "a voting paper or polling booth, a barrister's brief or a lecturer's platform." 22 The implication was clear: women suffered no loss of talent and drive because of "the want of political rights." While many Catholic commentators shared this sentiment, they recognized the purely legal disabilities of women and sympathized with the claims a woman had to the work of her hands, to the property left her, to the care and custody of her children. When, in 1882, Parliament passed the Married Women's Property Act allowing a wife to keep her own property without regard or concern for the wishes of her husband, the Catholic press supported the measure, albeit with some reservations. Writing in the Dublin Review in 1883, John George Cox said he feared that the Act would be used as an excuse to renew agitation on behalf of "the so-called women's rights movement." ${ }^{23}$ In his view the claims of its leaders were fanciful; the only real grievances of which women had a right to complain were the legal hardships that circumscribed their private lives as mothers and wives.

18. Ibid.

19. Ibid., 578.

20. "Women's Disabilities," Tablet, 4 May 1872, 543.

21. "Woman's Work," Month 22 (September 1874): 119.

22. "A French Study of Christian Womanhood," Dublin Review 88 (January-April 1881): 306. Barat (1779-1865) founded in France an international order of nuns: the Religious of the Sacred Heart. Seton (1774-1821) founded the American Sisters of Charity. Swetchine (1782-1857) was a Russian Orthodox convert to Catholicism and a wellknown woman of letters in France.

23. John George Cox, "The Changed Position of Married Women," Dublin Review 92 (January-April 1883): 441. Also see "The Married Women's Property Act," Tablet, 25 November 1882, 840; and "The Changed Position of Women," 5 May 1883, 685. 
Not until the late 1880s was the Catholic press inclined to discuss the marginality of women as due to their exclusion from the parliamentary franchise. Among the first to advocate change was the monthly, Merry England, edited by Wilfrid and Alice Meynell, both converts, she a poet, he a journalist, each a supporter of women's suffrage. In April 1886, they published E. M. Lyons's "The Cry of the Mothers," an essay which argued that guardianship laws were often "unsatisfactory" not simply because mothers had no say in crafting custodial practices, but because women were without a share in the parliamentary government to which they were subject. ${ }^{24}$ Other Catholics similarly deplored women's political inequality and complained that "it was painful" to note the Tablet's inability to express "intelligent sympathy" for "feminine activities." 25 A Conservative weekly, the Tablet was owned by the Reverend Herbert Vaughan; its principal editor, as of 1886, was John George Snead-Cox. Admitted to the Bar in 1881 but more interested in journalism, he was a friend of the Meynells and a relative of Father Vaughan who in 1872 had become the Bishop of Salford. Between 1888 and 1896, Snead-Cox and Vaughan departed from past editorial policy and set a course that, by the late nineteenth century, made the Tablet a notable supporter of women's suffrage.

Although the political segregation of women was to remain a source of tension in Catholic journalism, the Tablet resolved the issue-at least for itself-by reflecting the opinion of the Tory minister, Lord Salisbury. In December 1888, an editorial note informed readers that Salisbury had explained his advocacy of women's suffrage "on just the grounds we would have chosen for him," saying "not a word about inherent right" and wasting "no breath on theory or abstraction." ${ }^{26}$ What mattered to him "in an age so material as ours" was the influence that women naturally exerted "in the direction of morality and religion, as not only representing a fact, in the past, but as enshrining a policy for the future." Keeping Conservative opinion in mind, the Tablet reformulated its own position on women's suffrage and said in 1888: "we trust that when the Bill comes before the legislature, it will make no artificial distinction between married women and spinsters. All that Parliament has got to do is just to

24. E. M. Lyon, "The Cry of Mothers," Merry England 6 (April 1886): 398-407.

25. Tablet, 9 June 1888, 920; and letter to Tablet from "A Constant Subscriber," 23 June 1888, 1008.

26. Tablet, 8 December 1888,895 . For a detailed discussion of Salisbury's views, as well as his Conservative position, see Martin Pugh, The March of Women: A Revisionist Analysis of the Campaign for Women's Suffrage, 1866-1914 (Oxford: Oxford University Press, 2000, reissued 2002), 102-19. 
provide that henceforth no person shall be penalized and kept outside the pale of the constitution on account of sex." ${ }^{27}$

With this statement, the Tablet began to defend what it had earlier said was indefensible. Admittedly not all of its subscribers and certainly not all Catholics shared the journal's views. Cardinal Manning clung to the opinion he had expressed many years earlier that the exercise of the parliamentary franchise would demoralize women and diminish the influence they rightfully wielded as mothers and wives. Yet, he did not undervalue the talent of women. Manning recognized the work they had ably done on Boards of Guardians and County Councils, but he was unwilling to endorse a law that enfranchised not only women of intellectual and administrative ability but every woman no matter her qualifications. The discipline and dignity of domestic life counted far more than political pursuits, Manning believed. ${ }^{28}$ For him there was no acceptable rationale for favoring the workplace over the home. As the principal spokesman for Catholics in England, the elderly Cardinal naturally had many supporters, but among them were some who thought his opposition to women's suffrage was unfortunate and "a deficiency in the generally progressive ideas he held." 29 After visiting Manning in May 1891, the twentynine-year-old Virginia Crawford wrote in her diary: "we talked today about Woman's Rights in which the Cardinal goes much further than many of its opponents, ... but when it comes to the parliamentary franchise then he is quite obdurate. I told him I thought it was merely a remnant of the prejudice on his part."

When Manning died in January 1892, his successor at Westminster was Bishop Herbert Vaughan, then sixty years old. Like his predecessor, Vaughan understood the power of the press and was no stranger to the controversy surrounding women's suffrage. Unlike Manning, however, Vaughan supported the enfranchisement of women. In May 1896, the Tablet drew attention to his position, announcing "we are glad that the Cardinal Archbishop has declared himself in favor of

27. Tablet, 8 December 1888,895 .

28. Henry Edward, Cardinal Archbishop, "Leo XIII. On 'The Condition of Labour,'" Dublin Review 109 (July 1891): 165-66. Also, John Oldcastle, ed., Letters on Subjects of the Day by the Cardinal Archbishop of Westminster (Henry Edward Manning) (London: J. Sinkins, 1891); see letter to Monsieur Decurtins (July 1890), 12. This letter is discussed in the Tablet, 12 July 1890, 52. For Manning's views on women's suffrage, see Arthur Wollaston Hutton, Cardinal Manning (London: Methuen, 1892), 247; and Robert Gray, Cardinal Manning: A Biography (London: Weidenfeld and Nicolson, 1985), 297.

29. Hutton, Cardinal Manning, 247.

30. Shane Leslie, "Virginia Crawford, Sir Charles Dilke, and Cardinal Manning," Dublin Review 241 (autumn 1967): 194. 
votes for women." ${ }^{31}$ Vaughan did so when he wrote to the Women's Suffrage Committee and said: "I believe that the extension of the Parliamentary Franchise to women upon the same conditions as it is held by men would be a just and beneficial measure, tending to raise rather than to lower the course of national legislation." ${ }^{32}$ Along with the Tablet, he supported political inclusiveness, embracing the view that if the special interests of "unrepresented classes" were mishandled or ignored, then the remedy was to give the disenfranchised a voice in parliamentary governance. No one could misconstrue the Cardinal's intent. Even though the organized church remained aloof from the issue and there was, as yet, no corporate, lay support for the franchise, Vaughan sided with the suffragists.

$$
\text { II. } 1896-1910
$$

Despite Vaughan's endorsement, priests and parishioners felt free to voice their own opinions about the suffrage movement. Its political aspects occupied the public's attention to such an extent in the $1890 \mathrm{~s}$ that discussion and disagreement were nowhere unusual. When the Catholic Literary Society of Liverpool had debated female suffrage in 1894 , the speakers were all men, and those who opposed the measure reported their position to the recently founded weekly, the Catholic Herald. ${ }^{33}$ While the Tablet continued to advocate enfranchisement, the Month evidently believed there was so little reason to support political reforms that it published articles by Catholic women who were themselves suspicious of pleas for equality between the sexes. "Good, well-intentioned women," wrote $\mathrm{H}$. Walton in 1897, were "beguiled by the parrot shriek of emancipation" into forgetting "it was the will of God" that they should occupy a subordinate place to man. ${ }^{34}$ As for the women's movement, it championed "the aspirations of the few" and disregarded "the needs of the many," observed Ada Streeter in $1899 .{ }^{35}$ Even if she and others had reservations about political reform, certain priests suffered no qualms in criticizing the changing role of women. A well-known Jesuit, the Reverend George Tyrrell, believed that "the 'new woman' in her extreme type was an abomination to

31. Tablet, 2 May 1896, 687.

32. Ibid. For discussion of other priests who publicly supported women's enfranchisement, see Elaine Clark, "The Catholic Men's Share: Priests, Laymen, and Women's Suffrage in England," paper prepared for Research Seminar, University of MichiganDearborn, 2004.

33. Catholic Herald, 9 February 1894, 3.

34. H. Walton, "Of the Monstrous Regiment of Women," Month 89 (June 1897): 598. The author is a self-described "middle-aged spinster" (587).

35. A. Streeter, "Some Impressions of the International Congress of Women," Month 94 (August 1899): 179. 
Catholic instincts." ${ }^{36}$ In his view, professional restrictions seemed "natural, necessary, and desirable" in safeguarding the interests of women, since to challenge man's authority was "to weaken" the social fabric. $^{37}$

If priests, like Father Tyrrell, were of the opinion that the public sphere was properly masculine, they also discovered that not every Catholic woman quietly accepted the counsel of the clergy. This was notably the case in October 1897, when the Catholic Truth Society convened at Dundee under the chairmanship of the Archbishop of St. Andrews and Edinburgh, who was accompanied by the Bishops of Dunkeld, Glasgow, and Aberdeen. All heard Mrs. Cross Lynch speak of the work of women in the Society. Insofar as she was concerned, the problem at hand was not that a wife's "highest duties" were performed at home, but that "well-meaning people" looked to women "for nothing but buttons and mutton chops" and "strongly objected to them serving on School Boards in case the socks should go unmended and the bread unbaked." ${ }^{38}$ Her simple words expressed the tension felt by many Catholic women who were, in the later nineteenth century, caught between conflicting expectations. On the one hand, they were subject to the prescription that a woman had the unavoidable mission of making domesticity her sphere of activity. At the same time, they were members of a generation that saw political reformers challenge the forces of received opinion in order to afford women, no matter their status, a place in the public domain. For Catholic wives and mothers to arrive at a via media between a domestic vocation and civic engagement would require effort and also attention to the realities of a world wherein they had little experience of political debate.

Among the first to make herself heard as a Catholic feminist in a non-Catholic forum was Virginia Crawford. Writing in the Fortnightly Review in April 1897, she drew her readers' attention to the changes that characterized English and French thought in respect to the social position of women. "What we in England bluntly call women's rights," Mrs. Crawford explained, the French call "Feminism," and to it may be attributed much of the changing opinion of "our Gallic

36. George Tyrrell, S.J., "The Old Faith and the New Woman," American Catholic Quarterly Review 22 (July 1897): 631.

37. Ibid,, 644. Tyrell's literary collaborator and fellow actor in the "modernist controversy," Maude Petre, was also uninterested in the suffragist cause. See her essay, "Stray Thoughts on the Women's International Congress," Month 94 (August 1899): $186-93$.

38. Tablet, 23 October 1897, 674-75. For details of the Society, see V. M. Crawford, "The Work of the Catholic Truth Society," Tablet, 30 September 1905, 545-46, which notes that the main work of the CTS was to publish inexpensive Catholic literature. 
neighbours. ${ }^{39}$ In her view, even a small group of French Catholics, identifying themselves as "feministes Chretienes" in 1896, had come to share with better known "workers for the cause" the need to break down the old barriers of prejudice and misconception that hampered women's social development. ${ }^{40}$ A perceptive journalist and author, Mrs. Crawford was also familiar with Catholic activity in Belgium, Switzerland, and Italy. In 1901, when visiting Milan, she agreed to lecture, in French, on the subject of women's suffrage. Addressing a crowded meeting in one of the halls of the Archbishop's vast palace, Virginia Crawford became the first woman to speak publicly within the palace's precincts. ${ }^{41}$ Then, as later, Italian affairs interested her, but so did the position of her fellow Catholics at home. On various occasions she argued that Catholics in England had long been "accustomed to regarding themselves as almost a negligible quantity in the life of the country." ${ }^{2}$ For centuries they had no public existence, and in the early 1900s they still were a small minority living amid a dominant majority. But "the days are gone by," Mrs. Crawford noted in 1908, when Catholic women "could be content to be mere onlookers of contemporary politics." 43 She believed that within the boundaries of the Christian religion, there was ample scope for the political emancipation of women. Quite simply, they deserved to be heard in all that had a bearing on their social and economic progress. As for the usual objections of neglected families and self-absorbed lives, she disregarded these "assumed dangers," insisting they would "sink into insignificance" once Christian teaching was firmly grasped and cooperation prevailed in solving social problems. ${ }^{44}$ What mattered to Mrs. Crawford was that women organize and educate themselves to create a "feminist movement on Catholic lines." 45

During the first decade of the 1900s, as Mrs. Crawford knew, the work that Catholic women did to secure the franchise they usually did as members of nonsectarian societies. The Women's Social and Political Union (WSPU) as well as the Women's Freedom League (WFL) had Catholic supporters, as did "the milder and more constitutional of

39. Virginia M. Crawford, "Feminism in France," Fortnightly Review 67 (April 1897): 524.

40. Ibid., 534 .

41. Catholic Citizen, 15 April 1921, 37.

42. Virginia M. Crawford, “The Catholic Social Guild," Catholic World 95 (July 1912): 478. A similar argument was made by the Reverend John S. Vaughn, Tablet, 5 February 1898,307 ; and 18 November 1899, 830; also see comments of Father Grosch, 14 October 1905,625 .

43. Virginia M. Crawford, "Catholic Women in Italy Today," Catholic World 88 (October 1908): 3.

44. Ibid., 9.

45. Ibid. 
suffrage organizations," the National Union of Women's Suffrage Societies (NUWSS). ${ }^{46}$ These groups, which were founded with the purpose of securing particular ends, became schools of political training and the means for members to enter the public arena and engage in lobbying, demonstrating, speech-making, and collective protest. In 1906, when this protest involved the disorderly behavior of militant women, the Tablet defended the "so-called suffragettes" from the "cheap ridicule" heaped upon them by "scandalized journalists." ${ }^{47}$ Although "these ladies have gone to prison," the Tablet noted, "they are wise in their generation" and "have learned the lesson" taught by earlier reformers that legislators are influenced by public agitation. This lesson was not lost on Charlotte Despard, who reportedly "took her ashes on Ash Wednesday 1907," by heading a procession of women, including a number of Catholics, to the House of Commons to present a petition to the Prime Minister; the demonstration, which was disrupted by mounted police, led to her arrest and a fortnight's imprisonment. ${ }^{48}$

The example of Mrs. Despard, along with the militancy of the WSPU, brought a new intensity to Catholic discussion of the parliamentary franchise and helped to create closer ties between the populous Catholic north and the more noticeably convert south. Within this Catholic body there was a growing number of suffragists, particularly in Liverpool where Patricia Woodlock and Alice Morrissey actively supported the WSPU; both were well-known Catholics and members of the Independent Labour Party; both traveled to London to join suffragette demonstrations outside the House of Commons. By the spring of 1907, Patricia Woodlock had braved three prison terms. Mrs. Despard provided a home for her in London, while friends honored Woodlock as a courageous "prisoner of war." ${ }^{\prime 49}$ To the Tablet, she was a woman of conscience, showing the government that "Catholic advocates of women's rights" shared a faith of "no flimsy texture. ${ }^{\prime 50}$ Just as principled was Alice Morrissey. The president of the WSPU in Liverpool and a respected platform-speaker, she had been arrested in London in March 1907. Soon after her release from Holloway prison, Mrs. Morrissey told supporters that "so little deterred

46. "The problem of the suffragettes," Tablet, 9 October 1909, 561.

47. Tablet, 7 July 1906, 9.

48. F. C. Burnand, ed., The Catholic Who's Who \& Year-Book, 1909 (London: Burns and Oates, 1909), 137-38. Also see, Tablet, 23 February 1907, 298.

49. "Catholic Suffragists," Catholic Herald, 29 March 1907, 3. The daughter of David Woodlock, an artist, Patricia Woodlock was educated at Mt. Vernon Convent and at Manchester; her brother was a Jesuit priest.

50. Tablet, 23 March 1907, 457. 
was she by her recent experience that she hoped they would not rest until they had 76 women out of every large town in goal." ${ }^{51}$ Although the Catholic Herald had no interest in women's rights, its editor had published a "prison-letter" from Mrs. Morrissey, who claimed among other things that the franchise was an issue of liberty as well as justice. No nation was free while its women lived in "political silence," Alice Morrissey wrote, adding "history teaches us that it is only by some people making sacrifices, that we will be freed." ${ }^{52}$

Along with Alice Morrissey, militant women in Leeds and Newcastle upheld a tradition of sacrifice in service of a greater good. By 1914 Bertha Quinn, "a clothing operative" and labor organizer, would suffer imprisonment five times, but in 1909 she simply identified herself in the Tablet as a Catholic living in Leeds. ${ }^{53}$ Experience of industrial life led her to believe that the government, by refusing the just demand for female suffrage, had put millions of women at risk of "capitalist exploitation" in factories, workshops, and mills. "As a child," Bertha Quinn explained, "I learned in my Catholic catechism that oppression of the poor and defrauding labourers of their wages ranked with other foul crimes as crying for vengeance." ${ }^{154}$ With this lesson in mind, she embraced and defended militant methods. Hard times brought hard choices, and "sweet womanliness" failed to bolster the struggle for voting rights, according to outspoken reformers. Their message persuaded Violet Bryant to relinquish her position as a hospital nurse and work full time for the suffragist cause. When the hunger strike became a militant tactic, she was the first Catholic to suffer its consequences and bear "witness to her political convictions as also to her faith," said a letter to the Tablet..$^{55}$ Held in Newcastle Goal in October 1909, Violet Bryant refused to eat; she was handcuffed, forcibly fed, and confined to a punishment cell for seventeen days, all the while remaining firm in her resolve. "But when she was forbidden to go to Mass unless she took some food," Bryant relented, only to be forcibly "fed by tube" later in the day. ${ }^{56}$ On the following Sunday, after a Catholic priest intervened, "she was allowed to go to

51. "Catholic Suffragist Released," Catholic Herald, 5 April 1907, 1. The wife of Councillor Wolfe Tone Morrissey, she was also a Poor Law Guardian.

52. "Votes for Women," Catholic Herald, 26 April 1907, 10.

53. Tablet, 17 April 1909, 615. Also see "Caustic Lovable Bertha Quinn," Catholic Herald, 13 September 1951. Press Cuttings, Women's Library, London (hereafter WL), 2/SJA/ L23, p. 10.

54. Bertha Quinn to Tablet, 8 May 1909, 736.

55. "A Catholic Man" to Tablet, 26 February 1910, 736.

56. Tablet, 12 February 1910, 258. 
Mass fasting, that she might receive Holy Communion," the Tablet reported. ${ }^{57}$

To many people, Violet Bryant was an anomaly. Anti-Catholic propaganda had so long marginalized Catholic women that it was easy to think of them as absorbed in narrow concerns and too cowed by clerical authority to venture into the political fray. ${ }^{58}$ But this obviously was untrue of Bryant and like-minded women whose prison terms and public protest played a not unimportant part in raising awareness of a Catholic presence in the suffrage movement. Although subject to criticism, Catholic militants did find common cause with fellow Catholics who preferred constitutional methods of protest. Mutual respect and a corporate spirit mattered as much to Charlotte Despard as to Alice Meynell, an admirer of the nonmilitant NUWSS. When the National Union organized a demonstration on June 13, 1908, more than ten thousand women peacefully marched through London. A Catholic journalist later published his recollections of the day. "Some women," he wrote, "carried a favourite newspaper with its title bared to the long line of spectators," and because of this the Tablet "made strange company with the Clarion, in recognition, no doubt, of (the Tablet's) twenty years of approval of votes for women." ${ }^{59}$ As the procession made its way to the Albert Hall, Virginia Crawford appeared as an "eager organizer" of the event; Alice Meynell marched with her young daughter; and to Mrs. Despard, "many a stranger's hat was lifted as she passed along, a happy mother in Israel on this day of joy after many tribulations." 60

As dramatic as marches and demonstrations were, a number of Catholics publicly took an anti-suffrage stance and called for women as a body to hold aloof from the struggle for votes. Whether suffragists peacefully demonstrated, heckled politicians, or stormed the House of Commons, opponents of the franchise believed women belonged "at home." ${ }^{11}$ Writing to the Tablet in July 1908, Jessie O'Connor Poloveri confidently claimed "women do not want the

57. Ibid. For criticism of the hunger-strikes of suffragettes, see "The Ethics of Forcible Feeding," Month 119 (April 1912): 431-32; "The Ethics of the Hunger-Strike," ibid. 120 (September 1912): 313-14; "The Ethics of Forcible Feeding," ibid. 123 (January 1914): 90-91. For a discussion of prison life, see June Purvis, "The Prison Experiences of the Suffragettes in Edwardian Britain," Women's History Review 4:1 (1995): 103-33.

58. For references to women's supposed susceptibility to priestly influence, see "A Husband," letter to Tablet, 21 November 1868, 94; "Women's Franchise," 11 June 1884, 918. Pugh, March of Women, 45.

59. "The Women's Walk," Tablet, 20 June 1908, 962.

60. Ibid.

61. Agnes Gibbs to Tablet, 25 July 1908, 136. 
Parliamentary vote." ${ }^{\prime \prime 2}$ Among the Tablet's readers her statement initiated a heated discussion, sustained through letters to the editor, and lasting until July 1910. By then, fifty-three letters had argued the merits and faults of the suffrage campaign. The last letter deplored the anti-suffrage meeting held at the Queen's Hall on July 10, 1910, when the two principal speakers "in no uncertain terms declared that their real enemy was ecclesiasticism," then went on to argue that the power of the clergy "under women suffrage would be enormously enhanced," because "women were a prey to the allurements of a ceremonial Church." The letter continues: "I was astonished to realize that this avowed anticlerical movement is receiving the support of some of the leading Catholic M.P.'s" as well as "distinguished and influential members of the Catholic laity." ${ }^{163}$ Who they were, the letter failed to say, but many Catholics no doubt knew that Hilaire Belloc, a prominent layman and member of Parliament (1906-10), opposed women's suffrage. In July 1910, according to the Catholic Herald, Belloc had argued that under the current Suffrage Bill the country would have as voters "every disappointed woman who could not or would not bear children ... every spinster, every woman who had quarreled with her husband and kept a separate establishment, every woman who wished to lead her own life... everyone with a grievance against her Creator." ${ }^{64}$

If Belloc's opinions exasperated a number of his fellow Catholics, he had the uncompromising support of Charles Diamond, the founder and editor of the Catholic Herald. His litmus test for public figures was the stand they took on Irish Home Rule. In Diamond's opinion, Belloc was "a thick and thin supporter of the Irish party," whereas Millicent Fawcett, the president of the NUWSS, was an "anti-Home Rule agitator," with an "anti-Irish" bias that "sullies the cause of women's suffrage." ${ }^{\prime 65}$ A judgmental man, Diamond disliked the fact that the NUWSS and other women's groups would support Unionist candidates simply because they favored female suffrage. Irish party leaders were averse to Unionists and opposed giving women the vote. Diamond was little different and used the Catholic Herald to taunt Mrs. Fawcett and the more militant advocates of women's rights.

62. Tablet, 11 July 1908,60 .

63. "A Catholic Suffragist" to Tablet, 16 July 1910, 95.

64. "Mr. Belloc on Woman Suffrage," Catholic Herald, 16 July 1910, 3. Also see, Tablet. 16 July 1910, 78 .

65. "Suffragettes and Mr. Belloc," Catholic Herald, 7 May 1910, 5; "The Destructive Celt: Mrs. Fawcett's Outburst of Narrowness," 27 August 1910, 5; "Woman Suffrage," 6 April 1912, 3. 
When, as occasionally happened, the clergy joined this discussion, they were hardly of one mind regarding the women's movement. Among the more vocal of Catholic priests was the Jesuit Father Henry Day. In December 1908, he made the franchise the subject of a sermon he preached in the church of the Holy Name, Manchester. "From the standpoint of Christian ethics," he said, "I see no reason why unmarried women who possess property," should not have the vote, but "in regard to a married woman the case is different." To allow a wife the franchise would either confer "two votes" on her husband or create marital discord and "family friction." "A woman may be a voter but this adds nothing to her dignity," Day argued, because her "highest destiny" is "to people the world with men." 66 The Jesuit, Terrence Donnelly, spoke just as frankly in February 1909, when he delivered a Sunday evening lecture in Stamford Hill. Admitting that he "personally would have no hesitation in giving women their votes," he noted there was good reason to fear a "socialist" element in the suffrage movement. Given this worry, Donnelly insisted that the "liberty" of women was not so much guaranteed by the parliamentary franchise as by the Catholic Church, since a priest in the confessional was able to "teach" a woman "her rights." ${ }^{\text {"67 }}$ Wilfrid Carr, himself a parish priest, more forcefully defended the parliamentary franchise in April 1909, when he chaired a suffrage meeting in Formby (near Liverpool). Because Mary Gawthorpe, the main speaker, was unexpectedly detained, Father Carr briefly addressed the audience, saying he "sympathized with the cry of votes for women" and believed the parliamentary franchise would better the social and spiritual condition of men as well as women. "He knew of no moral law or principle of expediency why a woman should not have the vote on the same terms as a man." 68 When critics denounced the "extreme measures of the suffragettes," he admitted he also was concerned, although "it was a principle in constitutional agitations," he argued, "that you cannot secure a hearing unless you make a row." ${ }^{69}$

The limited presence of Catholics in the public arena made the political convictions of priests like Father Carr all the more notable. The Tablet described Carr's efforts on behalf of women's suffrage and reported, too, that Cardinal Moran of Sydney had endorsed the en-

66. “Woman: Wife or Voter?" Catholic Herald, 2 January 1909, 4.

67. "Some Modern Problems," Catholic Herald, 27 February 1909, 12.

68. "Suffragettes at Formby," Tablet, 17 April 1909, 624-25. Also, Rev. Carr to Tablet, 1 May 1909, 697. For biographical information on Mary Gawthorpe, see Holton, Suffrage Days, 115-36, 238-44.

69. Tablet, 17 April 1909, 625. 
franchisement of women in Australia. ${ }^{70}$ Closer to home, the Archbishop of Westminster, Francis Bourne, was by his own admission hesitant to discuss the "women question" in public, although Father Henry Day was not. ${ }^{71}$ In the autumn of 1909, at the church of St. Francis Xavier, Liverpool, he repeated what he had said in Manchester and argued that giving the franchise to wives and mothers would have a disastrous effect upon the home life of England. ${ }^{72}$ Even though many years earlier, reformers had belittled a similar argument, the belief persisted that women's suffrage was "incompatible with the high Catholic ideal of the unity of domestic life. ${ }^{\prime 73}$ In other words, "husband and wife were indissolubly one."74

By 1910 the Catholic Herald was more censorious of women's suffrage than even Jesuit critics had been. From the editor's office, Charles Diamond insisted that the campaign for votes was politically divisive, that its leaders wanted "to injure the Liberal government and the Liberal Party," that suffragettes openly indulged in "blackguard" and hysterical conduct. ${ }^{75}$ A long-time subscriber, Helen Breen, said in a letter to the editor, published on Christmas Eve 1910, "I cannot understand why your paper, always in the forefront of the fight for liberty, should refuse such an elementary principle of justice as votes for women." ${ }^{\prime 76}$ Charles Diamond responded in an editorial note that left no doubt as to where the Catholic Herald stood: "we think (the suffrage movement) is a decadent symptom of the times and we do not admit that a majority of women ask for or desire it."77 That Diamond could make such an assertion raises a question not simply about the politics of the day but about what he left unsaid. To what extent did Catholics have a corporate and publicly recognized role in the campaign for the parliamentary franchise?

$$
\text { III. 1911-1914 }
$$

By the close of 1910, Catholic suffragists recognized the need for an organization of their own to bring Catholic women more fully into the

70. Tablet, 6 February 1909, 226. Also see Rev. Morgan M. Sheedy, "The Church and Woman-Cardinal Moran's Views," Catholic Herald, 24 June 1911, 5.

71. Tablet, 1 October $1910,549-50$.

72. Tablet, 6 November 1909, 725-26. Also see "The Church and Woman's Rights," Catholic Herald, 30 October 1909, 6.

73. David Barry, S.T.L., "Female Suffrage from a Catholic Standpoint," Irish Ecclesiastical Record, 4th series, 26 (September 1909): 301. For early criticism of such a position, see "Shall Women Vote," Tablet, 14 July 1883, 38.

74. Barry, "Female Suffrage," 301.

75. Catholic Herald, 24 Decemer 1910, 6.

76. Ibid.

77. Ibid. 
suffrage movement. Gabrielle Jeffery and May Kendall provided the lead, joining seven fellow suffragists in March 1911 to create the Catholic Women's Suffrage Society (CWSS). Individually and as a group, the founding members were, in Virginia Crawford's words, "tres feministe et tres orthodoxe"; one belonged to the NUWSS, the others to the WSPU; one was a convert, the rest were "born Catholics. ${ }^{\prime 78}$ Each agreed that the object of the CWSS was "to band together Catholics of both sexes, in order to secure for women the Parliamentary vote on the same terms as it is or may be granted to men."79 The Society was nonparty, and its intention was to carry on constitutional and educational work without recourse to militant methods. Although men might become associate members, they could not vote for or be elected to the executive committee. When Cardinal Bourne learned of the Society, he said his position precluded him from expressing any official opinion.

Undeterred by the Cardinal's noncommittal stance, the members of the CWSS pursued the work of organization with unfailing energy and drive. Early in 1911, notices placed in the London press said the CWSS was "the newest of many suffrage societies," and had an "unselfish" desire to secure a share of political power for millions of working women whose economic well-being was threatened by "the hard and even de-humanizing" conditions of the workplace. ${ }^{80}$ Not long afterwards, on June 10, the CWSS held its first public meeting at Kensington Town Hall, where May Kendall explained that the CWSS refused to employ confrontational tactics but admitted militants as members, provided they agreed not to represent the Society at militant demonstrations. ${ }^{81}$ What clearly mattered to her was a sense of inclusion and Catholic solidarity in the cause of women's enfranchisement. By the time the meeting was adjourned, eighty-six women had applied for membership, increasing the numbers of the CWSS to roughly two hundred. ${ }^{82}$ A week later, on June 17, a group of Catholics met at London's Blackfriars Bridge and from there joined thousands of suffragists in the Women's Coronation Procession. The Catholic contingent included eighty members of the CWSS, many wearing religious medals or sodality ribbons, some representing the Children of Mary, others saying the rosary as they marched towards the Albert Hall. Along the way sympathetic bystanders saluted the marchers,

78. Catholic Citizen, 15 September 1923, 12. Also, de Alberti, "A History," 78.

79. Ibid.

80. Ibid., 77. Tablet, 13 May 1911, 738.

81. Tablet, 17 June 1911, 930; also, "Catholic Suffragists," Catholic Herald, 17 June 1911, 1.

82. "Catholic Suffragist" to Catholic Herald, 29 July 1911, 2. 
urging them on with cheers of "Bravo, Catholics," followed by shouts of "Home Rule for Ireland." ${ }^{83}$

As memorable as the Coronation Procession was for spectators, it became something more in the annals of the CWSS, marking the first time its members joined other suffrage societies in a public show of support for their common cause. Given the importance of favorable publicity, no political group was indifferent to public opinion. After all, "a good many people imagined Catholicism was opposed to the suffrage movement," Florence Roche told a CWSS meeting in 1911. ${ }^{84}$ Equally worrisome, claimed Kathleen Fitzgerald, was the "idea entertained by many non-Catholics that women were a negligible quantity in the Catholic Church. ${ }^{115}$ Since a number of Catholics still harbored misgivings about the suffrage movement, the CWSS believed it had a message to deliver, namely, that the extension of suffrage to women, "far from being contrary to the teaching of the Church," was completely in harmony with Catholic doctrine. ${ }^{86}$ Even so, the initial efforts of the CWSS to influence and enlighten public opinion met with resistance. One difficulty, observed Christopher St. John, was the unsparing criticism aimed at Catholic suffragists (of whom she was one) "for forming a separate society." 87 The Catholic Herald, the Universe, and the well-known Catholic novelist, Josephine Ward, demanded to know by "what right and title" a women's suffrage society styled itself "distinctively Catholic." And this was not all. "Why connect the name of the Church with a matter so controversial" in nature as votes for women? ${ }^{88}$

Questions as pointed as these elicited candid responses. The "title CWSS," members explained, simply advertised the fact that certain Catholic women favored the parliamentary franchise. They supported a Catholic society because they believed in "united prayer" and understood that "religion had a great deal to do with social reforma-

83. “A Significant Event," Ave Maria 73 (September 1911): 404-6. Also, "London Gleanings," Catholic Herald, 24 June 1911, 1; and "March of 40 Thousand," Tablet, 24 June $1911,976$.

84. Catholic Times, 4 November 1911. Press Cuttings, WL 2/SJA/L1, p. 10.

85. Tablet, 25 November $1911,850$.

86. "Catholic Women's Suffrage Society," as officially contributed by CWSS to The Suffrage Annual and Women's Who's Who, ed., A. J. R. (London: Stanley Paul, 1913), 17.

87. Tablet, 25 November 1911, 850.

88. "Catholic Suffragists," Catholic Herald, 24 June 1911, 8. "The Abadamites," Universe, 20 December 1912. Press Cuttings, WL 2/SJA/L1, p. 114. Josephine Ward to Tablet, 10 August 1912, 223-24. Her husband, Wilfrid Ward, believed the suffrage movement was the "result of hysteria," Tablet, 14 March 1914, 401. For non-Catholic support of a specifically Catholic suffrage society, see Emily Wilding Davison's letter to Catholic Herald, 22 July 1911, 3. For her suffrage work, see Liz Stanley and Ann Morley, The Life and Death of Emily Wilding Davison (London: Women's, 1988). 
tion." ${ }^{89}$ All realized that only when women had the vote could they effectively influence the causes that mattered to them: education, temperance, international peace, and a single moral standard for men and women. There were, in effect, "no real grounds" for connecting the demand for the suffrage with an "essentially anti-religious movement," Mrs. Crawford said. ${ }^{90}$ The greater danger was for Catholic women to remain "silent" and "aloof." Although many were already involved in charitable work and philanthropy, these were endeavors of a circumscribed nature, separate from politics and limited to a kind of social "tinkering," said Alice Abadam. She believed the better initiative was for Catholic women to direct their energies to suffrage work and in this way "influence the lives of millions of their poor and unprotected sisters for the good." ${ }^{\prime 91}$ To say that politics and religion shared no common ground made little sense to the CWSS. An active member of the Society, Florence Barry told friends that "in the Church we have the corporal and spiritual works of mercy, so surely we should have political works of mercy too." 92

Mindful of political sentiment, the CWSS resolved to challenge not only lay apathy but clerical detractors of the campaign for women's rights. In Norwich, in August 1912, Alice Abadam appealed to the Catholic clergy not to misuse their great influence by promoting "indifference and uninformed opposition" to the suffragist cause. ${ }^{93}$ An eloquent platform speaker, she knew better than most the disadvantage the CWSS was at whenever priests spoke ill of the women's movement. In Liverpool and Preston, Father Basil Maturin had argued that women so profoundly "distrusted" one another that social progress was hindered not by men but women themselves. ${ }^{94}$ The Reverend Henry Day spoke just as harshly of women's political claims. During October and November 1912, Catholics in Manchester heard him say he was not so much concerned with a woman's right to the vote as her supposed "equal right with man to govern the coun-

89. Tablet, 25 November 1911, 850.

90. V. M. Crawford to Tablet, 17 August 1912, 262.

91. Tablet, 11 November 1911, 794-95.

92. Isabel Willis, "Ourselves and Our work," Catholic Citizen, 15 July 1923, 53. Nancy Stewart Parnell, "The Way of Florence Barry, 1885-1965," St. Joan's Alliance pamphlet (London, n.d.), 114.

93. "Catholic Women and the Suffrage," Tablet, 17 August 1912, 259.

94. "The Feminist Movement," Catholic Herald, 4 November 1911, 4; "The Catholic Women's League: Fr. Maturin on the Position of Women," 24 February 1912, 6. His statements were sharply criticized by Catholic suffragists; see, "Ladies' Opinions of Fr. Maturin's Lecture," Catholic Herald, 11 November 1911, 11; and "A Suffragist Member of the Catholic Women's League," 18 November 1911, 2. See, too, Monitor and New Era, 11 November 1911. Press Cuttings, WL 2/SJA/L1, p. 11. 
try." This "equality of right," Day insisted, "must be absolutely denied her." Moreover, no woman was man's "industrial equal"; nor did her work have "the same market value as his." As for the parliamentary franchise, Day claimed the State had the right "to refuse or grant the vote," albeit as a "matter of expediency and not justice." 95

An outspoken critic of "emancipated womanhood," Father Day was regularly quoted in the press and remained a controversial priest. Whenever he was in Manchester and Liverpool, Catholic suffragists gathered outside the churches where he preached and distributed leaflets supporting the CWSS. ${ }^{96}$ After newspapers began printing his sermons, Alice Meynell wrote to the Tablet in November 1912, calling attention to Day's self-described "fear" that votes for women would bring about "a revolution of the first magnitude." She remarked: "I say, most gravely, the vaster the magnitude of the revolution the better." ${ }^{97}$ Where Henry Day saw "danger" in the CWSS, Alice Meynell, the mother of eight children, saw a "fortress of safety" for Catholic women. So far as she was concerned, anti-suffrage rhetoric was "insolence." At a public meeting in Wimbledon, Alice Abadam said much the same and urged Father Day "to limit his commentary to theology" and avoid "the field of politics where he obviously was astray." 98 The Universe called her comments "arrogant" and labeled her supporters "paranoiac Abadamites," saying they all suffered from "incontinence of speech."

The more strident the criticism of the women's movement became, the more determined many Catholic suffragists were to influence clerical opinion. In December 1911, the CWSS wrote to the Archbishop of Westminster, the Rector of the Jesuits at Farm Street, and the Superior of the Brompton Oratory, imploring them to bear in mind "the grave need for the extension of the parliamentary franchise to

95. "Feminism and Its Evil Tendencies: Fr. Henry Day on Its Origins and Scope," Catholic Herald, 26 October 1912, 7; "The Church and Feminism," 9 November 1912, 3; "The Feminist Movement," 16 November 1912, 6; "Feminism," 23 November 1912, 7; "Degrading Feminist Teachings," 30 November 1912, 3. See, too, Tablet, 9 November 1912, 738-39; 16 November 1912, 789-90.

96. De Alberti, "A History," 93.

97. Tablet, 2 November 1912, 704.

98. "Catholic Suffragists and Fr. Henry Day," Catholic Herald, 2 November 1912, 4, and "Fr. Day's Critics," 8. Also, see editorial commentary defending Day in Universe, 2 November 1912; Press Cuttings, WL 2/SJA/L1, p. 84. When Day's sermons were reported in the Manchester Guardian, Christopher St. John criticized him in her letter to the editor, 5 November 1912, 87.

99. "The Abadamites," 114. 
women in the interest of justice, morality, and religion." ${ }^{100}$ None publicly responded until February 1913, when Cardinal Bourne explained in his Lenten Pastoral that Catholics were free "to admit or deny the expediency of allowing women to vote at Parliamentary elections." To him the franchise was a matter of politics, and he warned his "flock against the excess and possible moral faults" that could be "easily committed" through recourse to militant methods. ${ }^{101}$ In saying as much, Bourne expected Catholics to share and affirm his disapproval of suffragettes involved in stone throwing, window smashing, and property damage. Yet the CWSS issued no statement or letter of censure other than to say, as Kathleen Fitzgerald did in April 1913, "militancy is not our policy; ... we do not criticize other (suffrage) societies; ... the condemnation of Cardinal Bourne ... suffices." ${ }^{102}$ That she refused to denounce militants troubled the editor of the Month in whose opinion the policy of the CWSS fostered "the suspicion" that its members ignored the "immorality of militancy" and sadly underestimated the "criminal action" of suffragettes. ${ }^{103}$

Militancy was an obviously divisive issue among Catholics and never more so than when churches in London, including Catholic churches, became the targets of protesters. Their complaint was the government's ill-treatment of jailed suffragettes who were forcibly and cruelly fed during hunger strikes. By way of protest, militants disrupted Sunday services on June 7, 1914, at the Brompton Oratory where, during the midday Mass, a "well-dressed, middle-aged woman" stepped into the center aisle and cried out: "For Christ's sake stop forcible feeding." ${ }^{104}$ As the vergers rushed to remove her, a dozen women rose as one and chanted: "Oh God, save Emmeline Pankhurst and all our noble prisoners. Be with them in the hour of pain. Oh rouse this church and its priests to put an end to torture in the name of the Blessed Joan of Arc."105 Angry members of the

100. A loose copy of this letter is included in CWSS Minutes Book, vol. 2, WL 2/SJA A1/2. The letter is discussed in the Standard, 18 December 1911. Press Cuttings, WL 2/SJA/ L1, p. 15; Universe, 23 December 1911.

101. "Cardinal Bourne and Militant Suffragism," Catholic Herald, 8 February 1913, 2. Also, Tablet, 8 February 1913, 215.

102. "Catholic Women Suffragists: Interview with Chairman of London Society," Catholic Herald, 19 April 1913, 4.

103. "Whither UnCatholic Feminism Leads," Month 121 (January 1913): 88-89; and "The Catholic Women's Suffrage Society," 302-3. "The Progress of Militancy," ibid. 122 (July 1913): 84-85.

104. "The Militants at Work," Tablet, 13 June 1914, 920; and "Disturbances by Suffragists in London Churches," 930. "London Gleanings," Catholic Herald, 13 June 1914, 1; "Latest Act of the Furies," 4; and "Gossip of the Week," 8.

105. Catholic Herald, 13 June 1914, 4. "First Protest at the Oratory," Suffragette, 12 June 1914. Press Cuttings, WL 2/SJA/L3, p. 158. 
congregation ejected the "intruders," some of whom were roughly handled by crowds in the street. Later that Sunday at Westminster Cathedral, a woman "rushed up the steps of the old pulpit" and shouted: "In the presence of the Blessed Sacrament I protest the forcible feeding of women." ${ }^{106}$ By the next day four women had been arrested for disorderly conduct at the Cathedral and the Oratory. None was a Catholic; nor were the other protesters identified as Catholics by church personnel.

Although the Catholic press was quick to admonish all Catholics to condemn "lawless" protesters, the CWSS refused in June 1914, as it had in 1912 and 1913, to criticize militant suffragettes. "We do not sit in judgment on the consciences of our fellow women," said Blanche Smyth-Pigott"; neither are we theologians; ... it would be an unheard of thing that we should publicly decide what is and what is not sin." ${ }^{107}$ Instead the CWSS directed criticism, as it always had, at the opponents of the parliamentary franchise, claiming anti-suffragists denied women the opportunity "to help themselves" and failed to understand that women's "consciences" compelled them to work for reform. ${ }^{108}$ Theirs was not a sordid effort but a "sacred cause," observed Father T. J. Walshe of Liverpool. "Morality, temperance, and education" mattered to Catholics and would be more effectively safeguarded, he believed, "if the women of England had the vote." In his view, "every Catholic had a duty" from a religious standpoint to work in a "practical way for the cause." 109 Just as supportive of the women's movement was the Dominican Bede Jarrett, who gained the public's attention when he addressed a London meeting of international suffrage societies in July 1914. "I think it is only fair to say I represent nobody but my own conscience," he told the audience. "I am a Catholic priest, but I do not come in that capacity; ... I am here to say that... I support this movement because I consider that it makes for the better womanhood and manhood of this nation, because I consider it good for the temporal welfare of this Empire to which we belong, and also good for its spiritual welfare." 110 Had it not been for the outbreak of war in the following month, Father

106. "Latest Act of the Furies," Catholic Herald, 13 June 1914, 4.

107. Blanch Smyth-Pigott to Tablet, 27 June 1914, 1025; and 20 June 1914, 986.

108. Blanche Smyth-Pigott to Tablet, 17 August 1912, 262.

109. "Fr. Walshe, B.A., On the Women's Claim," Catholic Herald, 1 March 1913, 2. He lectured on suffrage in Liverpool as well as London; see Catholic Times, 19 June 1914. Press Cuttings, WL 2/SJA/L3, p. 60. See, too, "High Mass and Suffrage Sermon," Catholic Herald, 21 June 1913, 11.

110. "Women's Suffrage: Fr. Bede Jarrett Supports the Movement," Catholic Herald, 11 July $1914,7$. 
Jarrett's views certainly would have been much discussed in the Catholic press. But by the close of 1914, the public's interest in women's suffrage had given way to the tragedy of international conflict.

\section{IV. $1914-1928$}

While the CWSS lamented the horrors of war, it believed every suffragist had a solemn duty to further the progress of the women's movement. "It rests with us to see that the position of women is not worse after the war than it was before," concluded the Society's Annual Report for $1914 .{ }^{111}$ Mindful of war-time restrictions on the civil liberties of women, the CWSS discussed publishing a journal designed to counter opponents of the suffrage movement and to inform Catholics not only of "the feminist point of view" but of the work of women at home and abroad. ${ }^{112}$ Successfully launched in 1915, the Catholic Suffragist advocated a cherished ideal, namely, the value of constructive political change in the service of women's emancipation. Should members of the clergy or laity take a contrary stance, Catholic suffragists now had the means of mounting a concerted defense. As editor of the Catholic Suffragist, Leonora de Alberti set the tone, first criticizing the "narrow views" of Margaret Fletcher's "totally inadequate" history of Christian feminism, then deploring the "crude arrogance of an essentially male dogma fashioned by Father Augustine Rossler" to demonstrate "the inferiority of the female sex."113 The opinions of this Austrian priest, along with the anti-suffrage sentiments of the Catholic Mind, published by Jesuits in the United States, so annoyed the staff of the Catholic Suffragist that Blanche SmythPigott remarked in 1916: "we can only patriotically rejoice that we are English." 114

By 1917 the CWSS was clearly impatient with co-religionists whose opposition to women's rights seemed to involve personal prejudice

111. CWSS 3rd Annual Report, 1914, 4. WL 2/SJA.

112. Isabel Willis, "Our Own History," Catholic Citizen, 15 May 1920, 38.

113. Leonora de Alberti, "Christian Feminism," Catholic Suffragist, 15 January 1916, 4. Also, see her comments, "Women in the Catholic Encyclopedia," 15 July 1916, 63-64. For additional criticism of Fletcher, 15 April 1918, 29; and 15 December 1919, 93. Letters critical of Fr. Rossler's encyclopedia essay on women are in Tablet, 9 March 1918, 318; and 23 March 1918, 384. Rev. Augustine Rossler was a lecturer in sacred scripture at the Redemptorist House of studies in Maturn, Austria. Margaret Fletcher was the founder of the Catholic Women's League, which was "strictly non-political" and maintained "an attitude of rigid neutrality on the question of women's suffrage." See, Tablet, 30 May 1908, 843; and 16 March 1912, 423. For early history of the League, see Kane, "The Willing Captive of Home?"

114. Catholic Suffragist, 15 May 1916, 47. 
stubbornly mistaken for Christian principle. According to the Catholic Suffragist, antifeminist rhetoric was marred by "confused thinking and distorted theology" and did "incalculable harm," particularly when the public assumed that priests such as Father Rossler represented Catholic thought. ${ }^{115}$ The Church had no claim to pronouncing on political matters; nor did the CWSS exist as an official organization of the Catholic Church. The Catholic Women's Suffrage Society was, in fact, something more. With the passage of the Representation of the People Act (1918) and the enfranchisement of women over the age of thirty, the CWSS reaffirmed its public role as the first organization of Catholic women anywhere in the world to commit itself to equal suffrage. ${ }^{116}$

This commitment tempered the Society's response to the Representation of the People Act. The continuing disenfranchisement of younger women obviously troubled the CWSS, although its members allowed that legislation that had enfranchised "six million women, even on the wrong basis, is a very big advance." ${ }^{117}$ Grateful for reform, the Society sponsored a Mass of thanksgiving on February 17, 1918, at Westminster Cathedral, to which service non-Catholic suffragists, such as Millicent Fawcett and Margaret Nevinson, came. In the following months the CWSS intensified its organizational efforts, changing the name of the Catholic Suffragist to the Catholic Citizen, demanding the extension of voting rights to women under thirty, sending speakers to explain the Franchise Bill to women in London's Catholic parishes, and working tirelessly to make clear to co-religionists what Isabel Willis called "the essential Catholicity of our feminist creed." ${ }^{\prime 18}$ Among members there was a renewed determination to reform political life and to further the work and usefulness of Catholic women as citizens. Reflecting this resolve, the CWSS set an agenda which, in November 1918, opposed the unequal moral standards characteristic of the State's "Regulation of Vice," challenged all restrictions on women holding State office, demanded "equal pay for equal work," and advocated the representation of women in national groups involved in reconstruction and demobilization. ${ }^{119}$

Such an agenda would prove a hard task for a large suffrage organization, let alone the relatively small CWSS. Between 1913 and 1918, the Society's headquarters published rosters identifying 624

115. Ibid; and Catholic Citizen, 15 April 1918, 29.

116. Willis, "Our Own History," 39. Leonora de Alberti, "The International Women's Suffrage Congress," Catholic Citizen, 15 July 1920, 55.

117. CWSS 6th Annual Report, 1917, printed in Catholic Citizen, vol. 4: 13.

118. Willis, "Our Own History," 38.

119. "The General Election and the C.W.S.S.," Catholic Citizen, 15 November 1918, 87. 
financial donors: married women represented 32 percent of the donors; single women 59 percent; laymen 6 percent; priests 3 percent. Although no active members were nuns, the suffrage movement touched convent life. Of the early members of the CWSS, two had joined the Society of the Sacred Heart at Roehampton; two became Ursulines and another a Sister of Nazareth; one joined the Carmelites, one the Benedictines, and one the Cenacle Order. In February 1914, after Janie Christitch had entered London's Tyburn convent, she wrote to Mrs. Pankhurst: ${ }^{120}$

Your letter of January 29th has been sent on to me here where I am on trial hoping to be received into the Religious Life. This very fact will tell you that I cannot join in the deputation to the King, as I am, for one thing, bound to enclosure. I am however closely united to my sisters in the world who are fighting in the greatest movement of all times - the emancipation not of a nation or a race, but of a whole sex, the sex so marvelously honored by God Himself in the person of His Mother.

Since my future life will be chiefly devoted to prayer, I am pledged to direct (as far as my feeble spiritual weapons will permit) my burning desire for the moral and intellectual (both of which are implied in the political) status of women for the advantage of the Catholic Women's Suffrage Society.

I am afraid this is an occasion for me to resign membership from the W.S.P.U. which will always command my respect and have my sincerest good wishes.

To note the complex aspects of the suffrage movement, as Janie Christitch did, was hardly unusual. Her mother often claimed that "Catholic women, above all others, have known wide responsibility," because allegiance to a universal church "carried their minds outside immediate private cares, over distant seas, to the remotest corners of the globe." ${ }^{21}$ Given this concern for women in "other lands," the Catholic Citizen in 1920 launched "International Notes," a monthly column written by Virginia Crawford, with additional information provided by Leonora de Alberti, Elisabeth Christitch, Annie Christitch, and Helen Douglas Irvine. Realizing the CWSS was "the pioneer of suffrage in the Catholic world," they discussed the political circumstances of this larger world and thoughtfully used its many languages, communicating with co-religionists and fellow suffragists in French, Spanish, Catalan, Portuguese, Italian, German, Serb, and

120. J. Patricia Christitch to Mrs. Pankhurst, Christitch Archives, Boston College, John J. Burns Library, MS 94-39, folder 2.

121. Elisabeth Christitch to Tablet, 24 August 1912, 303. 
Croat. ${ }^{122}$ What ultimately resulted was a far-flung network of friends and supporters, all sharing the CWSS's conviction that their religion promoted "work for the welfare of humanity" and encouraged the participation of women in international life. ${ }^{123}$

Catholic suffragists knew, however, that certain members of the hierarchy perceived the international suffrage movement as "hostile to the Catholic Church." ${ }^{124}$ Not only was this an "erroneous impression," Isabel Willis claimed, but the "Catholic point of view" was best served if it was vigorously represented at international congresses. ${ }^{125}$ When the International Woman Suffrage Alliance met in Switzerland in June 1920, the CWSS sent its own delegates and arranged for Father Herbert Hall of London to celebrate Mass in Geneva. At the church of Notre Dame, he asked "divine guidance for the International Women's Congress," then took the pulpit to say that "the women's movement was a stately ship fairly launched and well started on her voyage." He noted there had been a "troubled period" when the CWSS was "the object of prejudice, suspicion, distrust, contempt, and derision." To counter this bias, Father Hall urged his audience never to forget that the suffrage movement "arises from the noblest human instinct of benevolence towards those who suffer wrong." 126

The CWSS believed that the support of Father Hall and his fellow priests was nowhere more important than in countries still opposed to votes for women. The American suffragist and leader of the international suffrage movement, Carrie Chapman Catt, thought much the same. When the CWSS welcomed her to London in December 1920, Mrs. Catt reminded her hostesses that "practically the whole world had been won to suffrage with the exception of the Latin Catholic countries." She appealed to the CWSS to help its sisters in these countries by urging "every high ecclesiastical authority to endorse the good that woman suffrage had done... Y You have a great work to do," Mrs. Catt said; "you must keep on for the world calls you, and calls you with great earnestness." ${ }^{127}$ Not long afterwards, the editorial

122. Catholic Citizen, 15 July 1920, 55; 13th Annual Report, 1924, (printed in vol. 5: 25), noted that the Catholic Citizen "is exchanged with over 100 Catholic and Feminist papers in this and many foreign countries."

123. Christopher St. John's remarks to 24th Annual Meeting; see Catholic Citizen, 15 March $1935,32$.

124. Isabel Willis to Tablet, 6 March 1920, 329-30.

125. Isabel Willis to Tablet, 29 March 1920, 728.

126. "Catholic Delegates at Geneva," Catholic Citizen, 15 July 1920, 56.

127. "Mrs. Chapman Catt's Message to CWSS," Catholic Citizen, 15 December 1920, 95. Also Tablet, 11 December 1920, 802. Virginia Crawford, as Chair of St. Joan's Alliance, also argued that "Catholic women had a definite part to play in international feminism especially in the Latin countries." Catholic Citizen, 15 April 1926, 34. 
staff of the Catholic Citizen emphasized once again the need "to spread the gospel of feminism" among co-religionists abroad. ${ }^{128}$ "We shall have to take the enfranchisement of women in other lands as seriously as we take our own," Leonora de Alberti observed, encouraging the CWSS to devote time and effort to creating an apostolate of "Catholic Feminism. ${ }^{129}$ When this effort was questioned by Cardinal Bourne in 1923, the CWSS learned of the Vatican's ruling that "no Society, calling itself Catholic, may take part in or be officially represented at any meetings of a non-confessional, Protestant, or neutral nature." 130 The problem for Catholic suffragists was their affiliation with the International Woman Suffrage Alliance. Rather than withdraw from the Alliance or accept a spiritual advisor, as Cardinal Bourne wanted, the CWSS chose to maintain its independence and forgo recognition as a formally sanctioned Catholic society. After much discussion, members renamed their organization, omitted the word "Catholic," and in October 1923 became known as St. Joan's Social and Political Alliance.

As "a political body of Catholic women," St. Joan's Alliance sought to raise and enhance the status of all women. ${ }^{131}$ In 1926 , when the campaign for equal citizenship was in full swing, thirty organizations supported St. Joan's Alliance at the suffrage meeting it hosted in London's Caxton Hall. Dame Millicent Fawcett was a featured speaker as was the widely respected Catholic bishop, William Brown. As chair of the Alliance, Virginia Crawford presided and spoke on behalf of a resolution demanding voting rights for women at the age of twenty-one and on the same grounds as men. In supporting this resolution Bishop Brown explained that he had "lived and worked for forty years among working people" in southeast London and deplored "the injustice inflicted on the working women of this country in not getting the vote." ${ }^{132}$ The fight that had wrested voting concessions from a reluctant government in 1918 would not end, he believed, until the industrial womanhood of England had the parliamentary franchise.

Not only Bishop Brown but St. Joan's Alliance had long understood the need for Catholic leaders to respond to the concerns of women

128. Leonora de Alberti, "Our Work Abroad," Catholic Citizen, 15 March 1921, 26.

129. Tbid.

130. Catholic Citizen, 15 May 1923, 39; and 15 November 1923, 87. Also see CWSS Minutes Book. WL 2/SJA A1/5, vol. 5, 27 March 1923.

131. Leonora de Alberti, "The Work of St. Joan's Social and Political Alliance," Catholic Citizen, 15 January 1928, 4 .

132. Bishop Brown as quoted by Leonora de Alberti, "The Equal Franchise Campaign," Catholic Citizen, 15 May 1926, 41. 
workers. As a result, the issues discussed and debated by the Alliance ranged across a broad spectrum-from protective legislation and the representation of women in industrial councils, to family endowment, widow's pensions, and child welfare. Of course, these issues were hardly exclusive to St. Joan's Alliance and involved other women's organizations as well. Throughout the 1920s the Women's Freedom League and the National Union of Societies for Equal Citizenship called on Catholic suffragists to join fellow activists as they testified before government committees, demonstrated outside the House of Commons, lobbied members of parliament, and in 1928 triumphantly celebrated the passage of the Equal Franchise Bill. St. Joan's Alliance marked this historic occasion with a Mass of thanksgiving in Westminster Cathedral, followed by a procession of Catholic and Protestant suffragists, which included Millicent Fawcett and Charlotte Despard, walking alongside Elvira Laughton Mathew, aged two-anda-half and representing "the rising generation."133

As the campaign for the vote drew to a close, members of St. Joan's Alliance paused to remember the struggle that had brought them together in "a great sisterhood of sacrifice and endeavour."134 Some had "grown up in the women's movement," while others had "grown old in it." 135 By 1928, Charlotte Despard was eighty-four; Alice Abadam was seventy-two; Virginia Crawford, Elisabeth Christitch, and Leonora de Alberti were in their late sixties; Christopher St. John was fifty-three. Together they remembered the suffrage movement in its earlier days as having had the character of a meeting place where unenfranchised women, of whatever religion, had found common cause. Leonora de Alberti recalled the years around 1905 when Catholics "came into the women's movement on the crest of militancy" and in support of the Women's Social and Political Union. She recalled, too, that after the CWSS was founded in 1911, "many of us" also belonged to militant societies, although "at a later day" the CWSS grew "very friendly" with Millicent Fawcett. "If she came to our meetings and prefaced her remarks by reminding her audience that she was a Protestant, we laughed since no one had forgotten it." ${ }^{136}$ Nor had anyone forgotten that most suffragists "were drawn from

133. Leonora de Alberti, "Victory. Deo Gratias," Catholic Citizen, 15 July-August 1928, 57-59; also 15 July-August 1931, 59.

134. “Extracts from Miss Fedden's Speech: Annual Meeting of Children of Mary (4 October 1927)," Catholic Citizen, 15 February 1928, 14.

135. Catholic Citizen, 15 March 1935, 32.

136. Leonora de Alberti, "Dame Millicent Fawcett," Catholic Citizen, 15 July-August 1931, $58-59$. 
Protestant churches and Catholics were but a small minority." 137 This being the case, Leonora de Alberti explained that "the chief object" of the CWSS had been to reach Catholics and bring home to them the importance of the suffrage movement. ${ }^{138}$ If, as she believed, this was the main contribution of the CWSS to "the suffrage fight," it was, she added, not the only one. Public opinion about Catholicism had gradually changed as well.

Although many people in the early 1900s identified the Catholic Church with clerical authority, the CWSS encouraged the public to see the church in broader, more inclusionary terms. Since its inception, the Society had promoted lay initiatives and was itself led by women who were not loathe to oppose priests and bishops on political issues. Just as notably, members of the CWSS supported non-Catholic societies and religious leagues in public demonstrations of solidarity for the suffragist cause. "The sight of Catholic and Jew, Anglican and Noncomformist," all occupying the same platform in Hyde Park and demanding votes for women, made "a strong impression on the public mind," observed the CWSS's Annual Report in 1914. ${ }^{139}$ This impression of Catholic cooperation and participation in civic debate remained sufficiently strong that various Protestant ministers applauded the CWSS for helping to lessen the "prejudice" and "misapprehension existing among our fellow countrymen regarding Catholics." 140

Where there was mistrust of Catholics and the belief that Catholicism both opposed modernity and threatened intellectual and economic progress, the political stance of the CWSS disarmed critics. Moreover, the Society's publications worked to promote a better understanding of what many Catholics had long rejected: an individualist language of women's rights. After the CWSS began pressing for electoral reform in 1911, co-religionists elsewhere followed its lead. In Scotland, Catholic suffragists began an organization of their own in November 1913. The Irish Catholic Women's Suffrage Association held its inaugural meeting during 1915. By 1920 the Catholic Women's Union of Croatia acknowledged its debt to England's CWSS, and in 1921 the Action Sociale de la Femme affiliated with the CWSS. In 1926 in Paris Virginia Crawford personally met with and offered organizational support to Catholic suffragists from Peru, Austria, France, and the Ukraine.

137. Ibid.

138. de Alberti, "A History," 79.

139. CWSS 3rd Annual Report, 1914, 2; WL 2/SJA.

140. de Alberti, "A History," 81. Also see CWSS 9th Annual Report, 1920, printed in Catholic Citizen, 15 February 1921, 19. 
The work of so progressive a society of women as the CWSS ultimately belied the traditional rhetoric and fixed images of Catholics as all alike, as reactionary, isolated, and forming a single, monolithic group. Far from being women apart, Catholic suffragists engaged England's political culture and transformed the CWSS from "one of the least among the feminist societies" in 1911 to one of the more publicly active in the $1920 \mathrm{~s} .{ }^{141}$ At the same time, members of St. Joan's Alliance, along with many fellow suffragists, made a persuasive case for internationalizing the discourse and goals of the women's movement. This was as much a priority for Virginia Crawford and Leonora de Alberti, the sometime editor of Jus Sufragii, as it was for Christopher St. John, who insisted that "the Alliance, like the Catholic Church, knew no frontiers." ${ }^{142}$ Insofar as she and others were concerned, the success of St. Joan's Alliance depended on international cooperation as well as the political skills of many Catholic women of intelligence, insight, and eloquence. That they did not find notable places in the posthumous history of the suffrage movement was seemingly due to what Christopher St. John called "a double prejudice: that of certain Catholics against feminism, and that of certain feminists against the Church." ${ }^{43}$ Despite this commonplace bias, Catholic suffragists still had a memorable story to tell-one that began in the 1880s, continued in the 1890s, and showed in the 1910s how they successfully created a public platform from which Catholic women could speak confidently to the world.

141. Catholic Citizen, 15 March 1935, 32.

142. Ibid.

143. Ibid. 